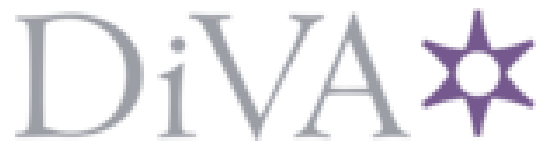

http://www.diva-portal.org

This is the published version of a paper published in Women - A Cultural Review.

Citation for the original published paper (version of record):

Åström, B. (2018)

Post-feminist fatherhood and the marginalization of the mother in Cormac McCarthy's the road

Women - A Cultural Review, 29(1): 112-128

https://doi.org/10.1080/o9574042.2018.1425539

Access to the published version may require subscription.

N.B. When citing this work, cite the original published paper.

Permanent link to this version:

http://urn.kb.se/resolve?urn=urn:nbn:se:umu:diva-146132 
Women: A Cultural Review

\section{Post-Feminist Fatherhood and the Marginalization of the Mother in Cormac McCarthy's The Road}

\section{Berit Åström}

To cite this article: Berit Åström (2018) Post-Feminist Fatherhood and the Marginalization of the Mother in Cormac McCarthy's The Road, Women: A Cultural Review, 29:1, 112-128, DOI: 10.1080/09574042.2018.1425539

To link to this article: https://doi.org/10.1080/09574042.2018.1425539

O 2018 The Author(s). Published by Informa
UK Limited, trading as Taylor \& Francis
Group




\section{Post-Feminist Fatherhood and} the Marginalization of the Mother in Cormac McCarthy's The Road

Abstract: Critics have tended to dismiss feminist analyses of Cormac McCarthy's works as misguided, labelling investigations of potential narrative misogyny in his novels as irrelevant. In this article, the author argues that such investigations are, on the contrary, bighly relevant in the current climate of mother-blaming. The author specifically explains how McCarthy's 2006 dystopian novel The Road uses post-feminist fatherhood to valorize the father and vilify the mother, thus participating in a continuing cultural trend of privileging fathers over mothers. The Road invokes traditional cultural expectations of motherhood and fatherhood, presenting the mother as unable and unwilling to care for the boy, in stark contrast to the very competent and able father. Many literary analyses of this bighly acclaimed novel have unquestioningly accepted the post-feminist marginalization of the mother, and critics have elaborated on and developed the motherblaming in the novel in a move that the author terms 'critical co-zeriting'. Critical cowriting occurs when critics ally themselves with an author, rather than retaining a critical distance, and represent the author's ideas without problematizing them. In the case of The Road, many critics build on post-feminist cues in the novel, adding their own, unreflected, understandings of motherhood and fatherhood. In so doing, they reinterpret 
and rewerite the novel into an even more forceful presentation of flawed mothering. In a critical discussion of these readings, the author demonstrates how these critics transform the novel's implicit criticism of the mother character into explicit condemnation.

Keyzoords: Cormac McCarthy, dystopian fiction, fatherhood, motherhood, post-feminism

Cormac McCarthy is generally regarded as one of the more important American novelists, and he is repeatedly put forward as a potential winner of the Nobel Prize for Literature. There are a number of booklength academic studies of his novels, as well as an academic journal devoted to his output alone: the Cormac McCarthy Journal. His novels, in particular the Pulitzer Prize-winning The Road (2006), are required reading at many universities. This makes analysis and critique of his novels all the more important. However, the starting point for many critics appears to be that McCarthy is a great author, thus making it the task of the scholar to investigate what makes his novels such great literature, rather than examining them critically.

This position is exemplified in Jay Ellis's keynote address at a conference on McCarthy at the University of Tennessee. In the address, Ellis describes the strategy he uses when approaching potential problems with The Road. He reminds himself of what he tells his students: that McCarthy is 'a living genius with a brain the size of Einstein's and a heart the size of Texas' (Ellis 2008: 31), and what at first appears to be poor characterization of the main character is thus resolved as an example of literary genius. Ellis's comment points to the following potential problem: if McCarthy's novels are approached with too much reverence, critical engagement becomes very difficult.

The foreclosing of critical conversations concerning McCarthy's work is particularly noticeable in responses to feminist analyses of his work. Feminist analyses are sometimes dismissed as oversimplifications or simply missing the point, failing to take into account the ingenuity, subtlety or genius of the text (Gamblin 2011). Indeed, it has been suggested that McCarthy's writing needs to be 'rescue[d] ... from accusations of misogyny which still seem to dog it' (King 2011: 639). Such suggestions imply that to examine critically the representation of women in McCarthy's novels is to focus on irrelevancies. The dominant discourse in McCarthy scholarship is to defend the writer from such attacks.

The reverent approach, and lack of a feminist perspective, is particularly noticeable in the critical engagement with the mother character in The Road. Expectations in many cultures demand that mothers be tender, nurturing 
and self-sacrificing. By contrast, fathers in many cultures are not required to care for their children, so if they choose to, they are treated as exceptional. Thus, the father's care for his son in The Road demonstrates a 'triumphant rugged masculinization of child care', provoking Naomi Morgenstern to label the novel 'a text for our time' (Morgenstern 2014: 34). Moreover, while acknowledging 'the novel's disturbing investment in getting rid of the mother', Morgenstern dispels any concerns over this by arguing that the father's care for the child constitutes 'mothering' (42). From this point of view, it is not a problem that the mother is killed off, since the father takes on the role of mother, in effect replacing her. This makes it possible for The Road, a novel that is heavily invested in promoting participatory fatherhood at the expense of motherhood, ${ }^{1}$ to be reclaimed as a progressive example of 'patriarchy narrating its own end' (34).

In this article, I discuss how McCarthy's seminal novel The Road and its critical reception construct motherhood as superfluous. The mother character is neither a traditional mother nor a 'new' mother. She is a non-entity with no relevance to the lives of her husband and son. By simultaneously reinforcing traditional stereotypes and embracing a 'new' fatherhood that is predicated on the elision of mothers, McCarthy and his critics present a futuristic world in which the only parent who is needed is the father. The mother is thus effectively written out of the family. ${ }^{2}$

1 The novel also invites in-depth analysis of men's appropriation of women's reproductive capabilities, but for reasons of space this cannot be investigated here. 2 A single father and child are often presented as a complete family, whereas a single mother and child tend to be constructed as an incomplete one (Åström 2017: 253-4). Morgenstern, for example, refers to the father and son as a family (Morgenstern 2014: 34).

\section{Cultural Images of Parenting, Post-Feminist Fatberbood and The Road}

Although the new millennium offers increasingly diverse ways of parenting, with new family structures and new definitions of the family, representations of motherhood still put forward traditional, normative stereotypes of selfsacrifice, often coupled with mother blame. In addition, motherhood is often marginalized in new formulations of fatherhood-in particular, postfeminist fatherhood, which represents mothers as superfluous or incompetent, especially in the raising of sons. These issues define the important considerations that have been neglected in analyses of The Road: the valorization of the father, the vilification of the mother and narrative misogyny.

\section{Cultural Images of Parenting: Self-Sacrificing Mothers and 'Exceptional' Fathers}

Although it has repeatedly been shown that real-life mothering changes with the society in which it takes place (Davidoff et al. 1999; Davis 
2012), and that there is, in fact, 'no essential or universal experience of motherhood' (O'Reilly 2004: 5), western cultural expressions of what is expected of mothers tend to reiterate a number of fixed characteristicsfor example, being unconditionally loving and self-sacrificing (Douglas and Michaels 2004; Ehrenreich and English 2005; Hays 1996). Notions of mothers being categorically selfless and unconditionally loving are also reiterated in many literary representations. The 'good mother' is portrayed as 'ever-bountiful, ever-giving, self-sacrificing' (Bassin et al. 1991: 2). These notions can significantly inform the expectations of readers and critics: in order to be a 'good mother', a woman should place her child's physical and emotional well-being before her own needs. In effect, she should live for the child. In The Road, the mother refuses to fulfil such expectations. Interestingly, this challenge to normative constructions of motherhood is represented as wholly negative within the novel. Moreover, it is frequently interpreted as such by literary scholars.

Cultural expectations of fathers have also traditionally placed demands on them as breadwinners, protectors and patriarchs. Although the traditional image of the stern, distant father has been problematized (Davidoff and Hall 1987; Johansen 2001), fathers have generally not been expected to demonstrate the same sort of self-sacrifice and unconditional love that has been demanded of mothers. Similarly, present-day fathers not only 'parent less than mothers', but they can also choose how much, or how little, they interact with their children, in a way that mothers cannot (Dowd 2000: 1). The degree to which a father involves himself in his child's life is thus seen as negotiable. Participatory fathers are regarded as exceptional. As will be discussed below, this cultural expectation informs the critical reception of the father character in The Road.

In the United States in particular, the extent to which fathers involved themselves in their children's lives changed substantially during the second half of the twentieth century (Kimmel 2013). This change is reflected in images of the father that emerged both in the media and in popular culture from the 1980s onwards. For example, television programmes such as The Cosby Show (1984-92), Family Ties (1982-9) and

3 One example Mary Douglas Vavrus discusses is how so-called ' $\mathrm{Mr}$ Moms'-men who became homemakers while their wives worked-were still presented within a heteronormative framework of 'paternal dominance' (Vavrus 2002: 353). Growing Pains (1985-92) showed fathers playing a significant part in their children's care and upbringing. Such representations constructed 'male nurturance and domesticity' as 'properly masculine' (Vavrus 2002: 353). However, these new fathers, intimately involved in their children's lives, still operated within hegemonic masculinity and, in fact, 'reinscrib[ed] patriarchal privilege within domestic space' (Vavrus 2002: 353). ${ }^{3}$ Hannah Hamad terms this intersection of hegemonic masculinity, domesticity and 'new' fatherhood 'postfeminist fatherhood' (Hamad 2014: 1). 


\section{Post-Feminist Fatberbood and Narrative Misogyny}

In her 2014 analysis of US films of the first decade of the twenty-first century, Hamad investigates the articulation of 'postfeminist fatherhood' (Hamad 2014: 1). Although there is critical debate about what 'post-feminism' means (Gill 2007: 147), a dominant idea is that the term reflects attempts to contain, neutralize and eliminate feminism as a necessary mode of inquiry. Hamad subscribes to this approach, specifically when she draws on the work of Angela McRobbie, as well as Yvonne Tasker and Diane Negra, who claim that post-feminism works to incorporate, assume' and 'naturalize' feminism in order to dismiss it as no longer needed (Tasker and Negra 2007: 2, 1). According to these scholars, postfeminism provides a way to circumvent feminist demands, suggesting that these have already been met. Feminism is now considered 'redundant' and 'a spent force' (McRobbie 2004: 255), or 'irrelevant, specious and silly' (Negra 2014: 279).

In traditional models of fatherhood, men have had to choose between masculinity and involved parenting (Kimmel 2013: 147). However, postfeminist fatherhood constructs caring for children-particularly boys-as a manly pursuit, making fatherhood the defining characteristic of a new form of hegemonic masculinity (Hamad 2014: 1). Hamad shows how the post-feminist father, as presented in popular culture, is often the sole caregiver. She argues that although the representation of men as caring and nurturing could be regarded as a positive development, such representations marginalize motherhood to allow for a 'discursive centralization of fatherhood' (Hamad 2014: 19). In other words, in much of popular culture, for the father and child-almost always a son-to bond, the mother must be removed from the scenario. This is often accomplished through her death (Åström 2015). Hamad claims that widowed fathers in post-feminist narratives enable a 'paternal postfeminist melancholia' that promotes audience investment in the fathers as they 'cement bonds with their children' (Hamad 2014: 24). This 'paternal postfeminist melancholia' is present in The Road. The novel details the man's grief for his dead wife, his longdead father and a dead world, as well as his very close relationship with his son.

This 'new' participatory father is not only able to connect emotionally with his children; he is also able to take care of the practicalities of childcare and the day-to-day running of a household (Hamad 2014: 2). Indeed, according to Jocelyn Elise Crowley, he is 'just like any modern mother' (Crowley 2009: 223). In fact, many post-feminist fatherhood narratives suggest that men are better parents than women, and The Road falls into 
this category. Throughout the narrative, the mother is contrasted with the father, and her many shortcomings suggest that the man is the only parent the child needs.

The Road's focus on the father as the only parent necessary ties in with the cultural notion that a mother 'cannot raise a boy into a man' (Kimmel 2013: 150)-that a son requires close contact with his father, and other men, in order to construct his own masculine identity. Not only is the boy's mother removed from the narrative and presented as incapable of taking care of the child, but the man also returns repeatedly to memories of his own father, as well as times spent with his uncle and other mentimes which appear to have been happy. In contrast, there is only one brief mention of the man's mother as someone who would not allow fires in the dining-room fireplace, since that would blacken the bricks (McCarthy 2006: 26). In other words, she refuses to 'carry the fire'-an important definition of humanity in the novel (see, for example, 83, 129, 283). ${ }^{4}$

The post-feminist valorization of fathers over mothers reflected in The Road serves as an example of the 'narrative misogyny' Nell Sullivan has traced in a number of McCarthy's works. This narrative misogyny is demonstrated through a 'lethal conflation of female sexuality with death' (Sullivan 2000: 73). In some of McCarthy's texts, this results merely in the death of female protagonists; in others, it appears as necrophilia and the keeping of corpses as girlfriends, as in Child of God (1973). In The Road, the man's memories of his dead wife are often sexual; she appears in his dreams as, in Sullivan's words, 'the beloved arrayed for death' (Sullivan 2000: 73): a corpselike 'pale bride' with 'pipe-clayed nipples', draped in 'gauze' (McCarthy 2006: 18). Although not as explicit as Child of God, there is a link between female sexuality and death in The Road as well.

Sullivan further argues that in McCarthy's works, female death often

4 Throughout the novel, the boy is concerned with the concept of 'carrying the fire', which he sees as something that defines good people. He seeks reassurance from his father that they are, indeed, 'carrying the fire' (83), and he will not join a new group of people after his father's death until he is reassured that they, too, are 'carrying the fire' (283). 5 Critics interpret the son's age as between 6 and 10 (Ellis 2008: 29; Spurgeon 2011: 18). becomes a 'plot device, or literal pretext, for bringing male characters together' (Sullivan 2000: 68; original emphasis). This is very much the case in The Road, where father and son are 'each the other's world entire' (McCarthy 2006: 6). There is no room for another person in their dyad. Thus, the paradigm of post-feminist fatherhood intersects with narrative misogyny to create a text in which there is no room for mothers.

\section{The Road}

McCarthy's dystopian novel charts the journey of an unnamed man and his young son through a cold and desolate landscape which may or may not be a post-apocalyptic United States (Morgan 2008). ${ }^{5}$ Regardless of whether the desolation was caused by nuclear war or perhaps a meteor strike, the disaster 
brings out the worst in most of the survivors. The man and the boy must negotiate their way through a world where people not only fight over what little food and resources there are left, but where humans are also hunted and eaten. ${ }^{6}$ Throughout the novel, the father and son debate what it means to be 'the good guys'-what the boy refers to as 'carrying the fire' (McCarthy 2006: 83). They struggle to retain some form of humanity when every person they meet is likely to be an enemy.

The narrative moves between descriptions of the pair's struggle for survival and the man's memories and internal monologues. Through these memories and internal conversations, the reader is afforded glimpses of the man's childhood, as well as of his wife. The boy was born shortly after the disaster and, for a while, the three of them travelled together. Faced with the hopelessness of their situation, the wife later decides to commit suicide. The man, on the other hand, promises himself that he will protect the boy at all costs, even if it means killing him-an idea that haunts him throughout the novel. In the end, the man dies without fulfilling this promise, unable to kill the child. After the father's death, the boy is found by a small group of people who appear to be 'good guys', since they 'dont eat people' (284).

The novel seemingly ends on a cautiously hopeful note, although the terse style makes such an interpretation uncertain. Indeed, a great deal of the critical interpretations have by necessity rested on inferences and assumptions, since very little detail and explanation are given. Additionally, the short sentences, often lacking a finite verb, sometimes make it unclear what character or event is being referenced. This opens up the text to a great number of interpretations. Some scholars read it as ecocriticism in its descriptions of a destroyed landscape devoid of animal life (see, for example, Grewe-Volpp 2013; Kollin 2011; Spurgeon 2011). Others interpret it as a discussion of ethics, morality and religion (see, for example, Carlson 2007; Gallivan 2008; Josephs 2013; Juge 2009; Vanderheide 2008; Wielenberg 2010). The novel has also been interpreted as a reworking of the Prometheus myth (Luttrull 2010) or the Grail narrative (Cooper 2011a), or as a postcolonial engagement with Robinson Crusoe (Hicks 2016). As far as I have been able to establish, however, there have been no substantial feminist analyses of the novel.

6 One particularly gruesome scene often referenced by critics is of 'a charred human infant headless and gutted and blackening on a spit' (McCarthy 2006: 198).

\section{Privileging the Father over the Mother in The Road}

In The Road, the father is pitted against, and trumps, the mother in three areas. In so doing, he shows that as a post-feminist father, he is a much better carer and guardian for the child than she is. First, he is emotionally involved with the boy and prepared to sacrifice himself for his survival, 
whereas the mother is emotionally distant and seems exclusively concerned with her own existence. Second, he is resourceful and quick-thinking. The mother, on the other hand, takes no independent action and appears to have no practical or survival skills. Third, the father is essential to the boy, even after his own death. The mother, in contrast, is quickly forgotten. Where the mother is constructed as expendable in every way, the father is presented as irreplaceable.

\section{Love and Self-Sacrifice}

It is repeatedly demonstrated in the novel that this post-feminist father is fiercely committed to, and emotionally involved with, his child. $\mathrm{He}$ makes it clear that he lives only for the boy: 'If you died I would want to die too', he states (McCarthy 2006: 11). In contrast, there are no such statements from the mother and no scenes in which she demonstrates any tenderness towards the child, or even speaks to him. Thus, even when the mother was alive, the boy appears to have been closer to his father. Although some critics assume that the father and son have been alone for most of the boy's life (see, for example, Gwinner 2011: 154), the text indicates that the mother lived with them for a number of years. This makes it all the more significant that only the father's devotion to the son is repeatedly expressed throughout the novel.

There is only one scene in the novel that depicts all three family members together. This is narrated in a flashback the man has, and it concerns his attempt to catch a dog, possibly to kill it for food. The wife walks away while the man is doing this; the boy remains, looking after her, then back at the man and finally at the dog. He begins to cry, pleading for the dog's life. No response from the mother is described; following the narrator's laconic statement that 'She walked away down the road' (McCarthy 2006: 87), she is not mentioned any further in the section. The reaction to the boy's distress comes instead from the father, who comforts the boy and promises not to hurt the dog. The mother is thus depicted as distancing herself from the family and not reacting to her child's distress, whereas the father breaks off his attempt at capturing the dog in order to console the child.

The difference between the parents is also evidenced in how they deal with the idea of killing the boy to spare him further suffering. In the one scene in which the mother is given space to explain her feelings and motivations-a four-page dialogue with the man, in which she outlines the futility of their situation before declaring her decision to leave the family and commit suicide-she calmly states that she would kill the child, since it is 
'the right thing to do' (56). Pointing out that it is inevitable that she and the boy will be raped, killed and eaten, she argues that murder-suicide is the rational action to take. The man, however, terms such talk as 'crazy' (56) -a sentiment echoed by critics. Lydia Cooper, for example, regards such a 'monstrous potential' as 'moral degradation' (Cooper 2011b: 139).

Throughout the novel, the man worries about having to kill his son, asking himself if he is the kind of person who could perform such an act: 'Is there such a being within you of which you know nothing?' (McCarthy 2006: 114). The question itself is so distressing that he must break off this chain of thought to hold the boy and kiss him. In the end, the man comes to the conclusion that he cannot 'hold my dead son in my arms' (279). This suggests that even though he may be physically capable, he is not emotionally so. Although killing the boy to spare him rape and murder could be interpreted as an act of mercy and love, the father does not view it in that way. His agonized rejection of the idea and expressions of love permeate the novel. This is pitted against the mother's brief, disinterestedly rational exposition, constructing her as callous and heartless.

Not only does the mother refuse to live for her son, but she does not exhibit a moment's remorse, anguish or worry about his future. The narrative describes the 'coldness' of her leaving as her 'final gift', showing the extent of her indifference towards her family (58). She leaves her husband and son, apparently without considering the impact it will have on them. ${ }^{7}$ The mother may be despondent, traumatized, depressed or simply choosing 'the terms of her own death over what she believes will be a more dehumanizing and tortuous ending' (Kollin 2011: 170). Nevertheless, the narrative's contrasting of the father's emotional outbursts-'I'm begging you' (McCarthy 2006: 55, 56, 58)-with the mother's unemotional responses invites the reader to sympathize with the father.

7 Phillip A. Snyder, opting for a 'straight hospitable reading', suggests that her suicide is a true gift-that the term is not ironic, since her death is intended to 'relieve' her husband and son of 'their responsibility for her responsibility' (Snyder 2008: 78).

\section{The Principal Parent: Male Competence and Female Incompetence}

A post-feminist father is 'domestically competent' and 'skilled in managing the quotidian practicalities of parenthood' (Hamad 2014: 2). Although the father and son are trudging across a post-apocalyptic landscape, which is neither domestic nor quotidian, their existence is filled with the repetitive tasks of finding food, lighting fires and making sure that they are dressed warmly. In fulfilling these tasks, the father is again privileged over the mother as a more capable guardian for the boy. No matter what difficulties they encounter, the man appears to be able to find a solution. It seems that as long as the boy stays with him, he will be safe. 
The narrative thus sets up a dichotomy between male survival skills and female incompetence in this regard. Not only does the man have an 'incredible knack for anticipating danger' on the road (Kearney 2012: 174), but he is also very skilled in foraging for useful items and repairing the ones they already have (see, for example, McCarthy 2006: 16-17). There are numerous scenes that demonstrate his ingenuity, quick-thinking, foresight, courage and strength of will (see, for example, 66, 95, 103, 122, 129, 266). The descriptions of these qualities establish the father as a good guardian for the boy. His skills and awareness of danger are contrasted with his wife's ineffectualness and impracticality. For example, when the disaster strikes, the man immediately understands the gravity of the situation and, anticipating that there will be a water shortage, fills the bathtub with water. His wife wonders why he intends to have a bath in the middle of the night (52).

Throughout the narrative, the mother's apparent lack of awareness of, and readiness for, dealing with disaster is juxtaposed with the man's preparedness; her emotional weakness contrasts with his dogged determination. Where the man refuses to give in, the woman does not even see herself as in charge of her own existence: 'I didnt bring myself to this. I was brought' (56). She does not expect to be able to protect herself or her child, and when she believes that her husband is not able to either, she decides to commit suicide. This is the only independent act of which she is capable. Ironically, when she commits suicide, she is relying on the technique her husband has taught her: 'She would do it with a flake of obsidian. He'd taught her himself (58). Even when it comes to committing suicide, it seems that the man is better prepared than the woman.

As the narrative presents it, the boy is fortunate that the remaining parent is the father, who can be relied on to protect him and provide for him-to 'assum[e] all roles of protector, nurturer and caregiver' (Woodson 2008: 88). That is to say, the man is both the better father and the better mother.

\section{The Principal Parent: Before and After Deatb}

The way the boy reacts to the deaths of his parents drives home how much more significant his father is for him than his mother. His only comment on his mother's disappearance is 'She's gone isn't she?', and he apparently accepts his father's laconic confirmation-'Yes, she is'-without emotion (McCarthy 2006: 58). He does not cry or mourn her. Considering how often the boy cries throughout the novel-over a stray dog, over a little boy he believes has been abandoned, over an injured man and over the 
potential death of a thief who would have left him and his father to die-it may seem remarkable that when the mother leaves, the boy is unfazed. However, since the only depiction of any interaction between them involves her walking away from him while he is in distress, readers are left to assume that she played no significant part in her son's life before she left.

While his mother's death hardly seems to register with the boy, his father's death deals him a great blow. When the father dies, the boy spends 'a long time weeping', holding his dead father's hand and calling his name 'over and over again' (281). Three days later, he is still crying. In total, six pages are devoted to the boy's grief, which stands in stark contrast to his quick acceptance of his mother's death.

The treatment of the parents' deaths and the boy's reaction to these sets up a dichotomy, with mother/death on one side and father/life on the other. The man's dreams of his wife are referred to as a 'call of languor and death' (18). After her disappearance, she remains only as a call of death to the boy as well. He mentions her once, saying that he wishes that he were with her. ${ }^{8}$ However, he does not wish for her to be with him and his father; rather, he wishes to join her in death. The man tells him that such thoughts must not be expressed: 'You mustnt say that ... Dont say that. It's a bad thing to say' (55). In this exchange, the boy's wish to be with his mother and his wish for death are conflated. In effect, the boy's father is asking him to reject not only the notion of death as an escape-thus rejecting his mother's choice and actions-but also any remaining need for her.

The father telling the boy to reject his mother's choice to give up is intimately connected with what constitutes 'good guys'-an important concept in the novel. As the father tells the boy: 'This is what the good guys do. They keep trying. They dont give up' (137). Shortly before his death, he repeats the message: 'You need to keep going. That's what good guys do' (278). Thus, the man himself exhibits a remarkable tenacity, refusing to give in to hopelessness and continually struggling on in the face of futility. The wife, however, sees no point in trying to survive and, having given up, only hopes for 'eternal nothingness' (57). In effect, she is not one of the 'good guys' and is thus forgotten, whereas the father will go on existing, even after his death, in his son's remembrance.

Shortly before he dies, the father tells the boy that even when he is dead, 'You can talk to me and I'll talk to you ... And you'll hear me. You have to

8 This is the only reference in the novel to the character as mother: 'my mom'. All other references are to 'his wife' or 'she'. practice. Just dont give up' (279). The boy obeys his father and does not forget him (286). As Donovan Gwinner observes, the father 'would appear to remain the most important person in the boy's life, in spite of his absence' (Gwinner 2011: 154). The narrative thus constructs the man as important, as a constant presence even after his death, whereas the 
mother seems to have been absent from the boy's life even before she left physically.

\section{The Road and Critical Co-zeriting}

Many critics of The Road have commented on the poignant portrayal of the father's 'limitless love' for (Wielenberg 2010: 10) and 'deep connection' to (Boxall 2013: 222) his son (see also Cooper 2011b: 140; Ellis 2008: 30; Gwinner 2011: 139; Spurgeon 2011: 17; Wilhelm 2008: 136). Thus, scholars who comment on the father's relationship with his son tend to treat it as a representation of unusually strong devotion and love; the man exceeds cultural expectations of a father's emotional involvement with his child. ${ }^{9}$

Although the novel presents a world in which notions of good and evil, right and wrong are called into question, where the characters must 'reconstruct belief systems, human relations and understandings of the self' (Kollin 2011: 158), some critics appear to assume that the concepts of what fatherhood and motherhood should involve are unchanged. For example, critics who read the man as a 'true hero' (Cooper 2011b: 136), struggling on behalf of all of humanity in a novel teaching lessons of morality, ethics and hope, apply traditional, normative expectations of motherhood to the wife and read the portrayal of her as an exemplum of how not to behave when faced with adversity.

Such readings seem in danger of a slippage from analysing the wife as a literary character, fulfilling a certain function in the novel, to describing her as a person failing to live up to the expectations traditionally placed on a good mother. In short, rather than analysing the character as she is presented, some critics appear to reproach her for what they think she is-someone who reneges on her responsibilities and who does not have the emotional

9 Carole Juge notes that the father's love gives him a 'resilience that overcomes many obstacles in the way'-that he fails in some of his efforts is less important, since 'at least he has tried' (Juge 2009: 24). Cooper also notes the father's resilience and that, although he does not quite succeed, 'at least he tries' (Cooper 2011b: 142). It is unlikely that such a comment would be made about a mother character. courage to go on.

This slippage is evident, for example, in Kevin Kearney's comments on what he calls the 'pejorative' and 'sexist' language the wife uses when referring to herself in the dialogue with her husband (Kearney 2012: 173; see McCarthy 2006: 55-8). She claims to have taken death as a lover, saying this makes her a 'faithless slut' (McCarthy 2006: 57), possibly echoing the 'conflation of female sexuality with death' Sullivan detects in McCarthy's earlier novels (Sullivan 2000: 73). Kearney, however, interprets the language as her self-criticism for not acting 'in a motherly way' (Kearney 2012: 173). Instead of preserving life as a mother should, Kearney argues, she 'extinguishes the life fire' and 'thwarts the female function of life bearer' (173), and the character, apparently aware that she is thwarting her 'female function', reproaches herself for it. I would argue that this exchange between 
husband and wife, revolving around death and futility, does not display 'a tension with her function as a female, of one who traditionally bears life' (173), but instead establishes the tensions between the two charactersone who intends to go on because 'That's what good guys do' and one who does not.

Other scholars extrapolate from the rational coldness the narrative ascribes to the mother and make her a symbol for all that is wrong with humanity, turning her into an Everywoman, the obverse of her Everyman husband. Cooper notes the 'mother's abject lack of pity for or emotional connection to her child', and interprets her as 'an embodiment of the egocentrism and faithlessness that are swiftly killing the planet' (Cooper 2011a: 223). The mother is selfish and disloyal, and to be criticized, rather than pitied, for her 'nihilistic belief in the pointlessness of human survival' (223). Her emotional state is even presented as one end of a sliding scale of 'dissociative behavior', with cannibals who roast infants on spits at the other, suggesting that being unable to commit emotionally to one's child is not far removed from eating it (223). Again, there is a slippage in the description, suggesting that what is discussed is not a narrative construction, but the character's failing as a mother. What seems to be implied is that she should have put her own problems to one side and focused on the wellbeing of her child. Thus, the critics create and reinforce an image of deficient motherhood.

Like Cooper, Randall Wilhelm reads the wife as an example not of egocentrism or faithlessness, but of a 'human mentality that succumbs to fear and doubt and deprivation because it cannot think beyond the limited scope of the self, one that too readily relinquishes the duty of life, an obligation to which the father so desperately clings' (Wilhelm 2008: 136). The character is criticized for being selfish, for giving up on her obligations 'too readily'. Considering the world the characters inhabit, it may seem somewhat harsh to judge a character in this way, but Wilhelm even goes so far as to suggest that the mother's belief in suicide as a solution is 'untenable, even immoral in the face of human suffering' (136). I would argue that it is exactly when faced with such relentless suffering that suicide becomes a viable option. However, in Wilhelm's reading, the mother is a bad parent and a bad human being, since she cannot see beyond her own immediate needs and does not make an effort on behalf of others. She refuses to carry out what is expected of her as a mother-to be unconditionally loving and self-sacrificing.

The novel consistently presents the mother as unable and unwilling to care for her son, thus highlighting the father's post-feminist achievements. The critics fasten on to this representation and develop it even further. Where the narrative demonstrates that the mother is ultimately irrelevant 
for the emotional and physical survival of the man and the boy, the scholars vilify her for shirking her responsibility, accusing her of an 'abject lack of pity', an inability to 'think beyond the limited scope of the self, and making 'immoral' decisions.

It should be noted that none of the critics discussed above devote more than a few lines, at most a few paragraphs, to the character. Yet in these brief references, she is dismissed with a surprising amount of vitriol. In this way, the post-feminist marginalization of the mother which begins in the novel is developed to a remarkable degree in the critical discussion.

\section{Conclusion}

In its representation of participatory, heroic fatherhood, Cormac McCarthy's The Road constructs the mother as lacking care, love, warmth, nurturing and survival skills. She contributes nothing to the family or the story, beyond giving birth to the child and acting as a foil for the father, who provides for the boy's physical and emotional needs. In so doing, the narrative represents this mother specifically and motherhood more generally as irrelevant. The novel participates in a continuing cultural trend of marginalizing mothers in order to privilege fathers. This is an aspect of the novel that requires much greater discussion and analysis than scholars have so far acknowledged or provided. It is a mistake to dismiss feminist analysis of McCarthy's works as misguided, to label investigations of potential narrative misogyny as irrelevant, or to claim that McCarthy's writing needs to be rescued from feminist investigations. Considering the iconic status of both the novel and its author, and the novel's place in undergraduate studies, it is a cause for concern that the misogynist construction of motherhood as irrelevant and deficient in the novel remains grossly under-examined. Scholarship that not only reads such portrayals without comment but also contributes to them does a disservice to McCarthy studies, and undercuts the critical importance of the relationship between fiction and the cultural context in which it is written.

\section{Disclosure Statement}

No potential conflict of interest was reported by the author.

\section{ORCID}

Berit Åström (1) http://orcid.org/0000-0001-7243-0059 


\section{Works Cited}

Åström, Berit (2015), 'The Symbolic Annihilation of Mothers in Popular Culture: Single Father and the Death of the Mother', Feminist Media Studies 15:4, pp. 593-607.

- (2017), 'Marginalizing Motherhood: Postfeminist Fathers and Dead Mothers in Animated Film', in Berit Åström (ed.), The Absent Mothers in the Cultural Imagination: Missing Presumed Dead, Basingstoke: Palgrave Macmillan, pp. 241-58.

Bassin, Donna, Margaret Honey and Meryle Mahrer Kaplan (1991), Representations of Motherhood, New Haven, CT: Yale University Press.

Boxall, Peter (2013), Twenty-First-Century Fiction, Cambridge: Cambridge University Press.

Carlson, Thomas A. (2007), 'With the World at Heart: Reading Cormac McCarthy's The Road with Augustine and Heidegger', Religion and Literature 39:3, pp. 47-66.

Cooper, Lydia (2011a), 'Cormac McCarthy's The Road as Apocalyptic Grail Narrative', Studies in the Novel 43:2, pp. 218-36.

- (2011b), No More Heroes: Narrative Perspective and Morality in Cormac McCarthy, Baton Rouge: Louisiana State University Press.

Crowley, Jocelyn Elise (2009), 'Taking Custody of Motherhood: Fathers' Rights Activists and the Politics of Parenting, WSQ: Women's Studies Quarterly 37:3-4, pp. 223-40.

Davidoff, Leonore, Megan Doolittle, Janet Fink and Katherine Holden (1999), The Family Story: Blood, Contract and Intimacy, 1830-1960, London: Longman.

Davidoff, Leonore and Catherine Hall (1987), Family Fortunes: Men and Women of the English Middle Class 1780-1850, London: Routledge.

Davis, Angela (2012), Modern Motherhood: Women and Family in England, 19452000, Manchester: Manchester University Press.

Douglas, Susan J. and Meredith W. Michaels (2004), The Mommy Myth: The Idealization of Motherhood and How It Has Undermined All Women, New York: Free Press.

Dowd, Nancy E. (2000), Redefining Fatherhood, New York: New York University Press.

Ehrenreich, Barbara and Deirdre English (2005), For Her Own Good: Two Centuries of the Experts' Advice to Women, New York: Anchor.

Ellis, Jay (2008), 'Another Sense of Ending: The Keynote Address to the Knoxville Conference', Cormac McCarthy Journal 6:1, pp. 22-38.

Gallivan, Euan (2008), 'Compassionate McCarthy? The Road and Schopenhauerian Ethics', Cormac McCarthy Journal 6:1, pp. 100-6.

Gamblin, Hillary (2011), 'Discovering the Romantic in a Necrophiliac: The Questions of Misogyny in Child of God, Cormac McCarthy Journal 9:1, pp. 28-37.

Gill, Rosalind (2007), 'Postfeminist Media Culture: Elements of a Sensibility', European Journal of Cultural Studies 10:2, pp. 147-66. 
Grewe-Volpp, Christa (2013), 'Keep Moving: Place and Gender in a Post-Apocalyptic Environment', in Greta Gaard, Simon C. Estok and Serpil Oppermann (eds), International Perspectives in Feminist Ecocriticism, London: Routledge, pp. 221-234.

Gwinner, Donovan (2011), "'Everything Uncoupled from Its Shoring”: Quandaries of Epistemology and Ethics in The Road, in Sara L. Spurgeon (ed.), Cormac McCarthy: All the Pretty Horses, No Country for Old Men, The Road, London: Continuum, pp. 137-56.

Hamad, Hannah (2014), Postfeminism and Paternity in Contemporary US Film, New York: Routledge.

Hays, Sharon (1996), The Cultural Contradictions of Motherhood, New Haven, CT: Yale University Press.

Hicks, Heather J. (2016), The Post-Apocalyptic Novel in the Twenty-First Century: Modernity beyond Salvage, Basingstoke: Palgrave Macmillan.

Johansen, Shawn (2001), Family Men: Middle-Class Fatherhood in Early Industrializing America, New York: Routledge.

Josephs, Allen (2013), 'The Quest for God in The Road', in Steven Frye (ed.), The Cambridge Companion to Cormac McCarthy, Cambridge: Cambridge University Press, pp. 133-45.

Juge, Carole (2009), 'The Road to the Sun They Cannot See: Plato's Allegory of the Cave, Oblivion, and Guidance in Cormac McCarthy's The Road, Cormac McCartby Journal 7:1, pp. 16-30.

Kearney, Kevin (2012), 'Cormac McCarthy's The Road and the Frontier of the Human', Literature Interpretation Theory 23:2, pp. 160-78.

Kimmel, Michael (2013), Angry White Men: American Masculinity at the End of an Era, New York: Nation Books.

King, Daniel (2011), 'Review of The Western Landscape in Cormac McCarthy and Wallace Stegner: Myths of the Frontier by Megan Riley McGilchrist', Journal of American Studies 45:3, pp. 638-9.

Kollin, Susan (2011), "Barren, Silent, Godless": Ecodisaster and the Post-Abundant Landscape in The Road, in Sara L. Spurgeon (ed.), Cormac McCarthy: All the Pretty Horses, No Country for Old Men, The Road, London: Continuum, pp. 157-71.

Luttrull, Daniel (2010), 'Prometheus Hits The Road: Revising the Myth', Cormac McCarthy Journal 8:1, pp. 17-28.

McCarthy, Cormac (1973), Child of God, London: Picador.

- (2006), The Road, New York: Vintage.

McRobbie, Angela (2004), 'Post-Feminism and Popular Culture', Feminist Media Studies 4:3, pp. 255-64.

Morgan, Wesley G. (2008), 'The Route and Roots of The Road', Cormac McCarthy Journal 6:1, pp. 39-47.

Morgenstern, Naomi (2014), 'Postapocalyptic Responsibility: Patriarchy at the End of the World in Cormac McCarthy's The Road', Differences 25:2, pp. 34-61. 
Negra, Diane (2014), 'Claiming Feminism: Commentary, Autobiography and Advice Literature for Women in the Recession', Journal of Gender Studies 23:3, pp. 275-86.

O’Reilly, Andrea (2004), 'Introduction', in Andrea O’Reilly (ed.), Mother Outlazes: Theories and Practices of Empowered Mothering, Toronto: Women's Press, pp. 1-28.

Snyder, Phillip A. (2008), 'Hospitality in Cormac McCarthy's The Road', Cormac Mc Carthy Journal 6:1, pp. 69-86.

Spurgeon, Sara L. (2011), 'Introduction', in Sara L. Spurgeon (ed.), Cormac McCarthy: All the Pretty Horses, No Country for Old Men, The Road, London: Continuum, pp. 1-22.

Sullivan, Nell (2000), 'The Evolution of the Dead Girlfriend Motif in Outer Dark and Child of God', in Rick Wallach (ed.), Myth, Legend, Dust: Critical Responses to Cormac McCarthy, Manchester: Manchester University Press, pp. 68-77.

Tasker, Yvonne and Diane Negra (2007), 'Introduction: Feminist Politics and Postfeminist Culture', in Yvonne Tasker and Diane Negra (eds), Postfeminism: Gender and the Politics of Popular Culture, Durham, NC: Duke University Press, pp. 1-25.

Vanderheide, John (2008), 'Sighting Leviathan: Ritualism, Daemonism and the Book of Job in McCarthy's Latest Works', Cormac McCarthy Journal 6:1, pp. 107-20.

Vavrus, Mary Douglas (2002), 'Domesticating Patriarchy: Hegemonic Masculinity and Television's "Mr. Mom”, Critical Studies in Media Communication 19:3, pp. 352-75.

Wielenberg, Erik J. (2010), 'God, Morality and Meaning in Cormac McCarthy's The Road', Cormac McCarthy Journal 8:1, pp. 1-16.

Wilhelm, Randall S. (2008), “Golden Chalice: Good to House a God”: Still Life in The Road, Cormac McCarthy Journal 6:1, pp. 129-46.

Woodson, Linda (2008), 'Mapping The Road in Post-Postmodernism', Cormac McCarthy Journal 6, pp. 87-97. 